\title{
Reformulating Political Party Court Procedures in Parties' Dispute Settlement
}

\author{
M Happy Agung Saputra* \\ University of Jember, Indonesia
}

\section{Iwan Rachmad Soetijono \\ University of Jember, Indonesia}

\section{Shofi Munawwir Efendi \\ University of Jember, Indonesia}

\begin{abstract}
The reformulation is a law enforcement stage by the legislature or a stage that is limited to the formulation of provisions regulated according to the current or future's condition. The Political Party Court is an important institution in the law enforcement procedure with a mixed-function- namely, regulator, administrator, and adjudicator - with a quasi-judicial. Internal dispute settlement through the Political Party Court was intended to ensure the parties' freedom and restrain the government interference that impacts the party's independence and their role as one of the institutions that have an essential duty to effectuate people's sovereignty. Therefore, the urgency of reformulation of the party's court procedures based on the principles of justice and accountability can become an answer to the political party's disputes. The law can strictly regulate this dispute settlement.
\end{abstract}

KEYWORDS: Reformulation, Political Party Court, Dispute Settlement, Political Party.

Submitted: 21/08/2020 Reviewed: 12/09/2020 Revised: 20/09/2020 Accepted: 25/09/2020

Copyright $\odot 2020$ by Author(s)

This work is licensed under a Creative Commons Attribution-ShareAlike 4.0 International License. All writings published in this journal are personal views of the authors and do not represent the views of this journal and the author's affiliated institution 


\section{INTRODUCTION}

The actualization of welfare state should be supported by three stakes, namely the state, which is manifested by government, the laws, and the officials who enforce it. ${ }^{1}$ The laws are formed to tackle the crimes, so the formulation must be appropriate with the present or future's needs. The legislation process can be carried out through several stages that are needed by new regulation, one of them is the formulation. The formulation process is an initial strategic stage of law enforcement. Mistakes or weaknesses in the formulation process can become obstacles to law enforcement. ${ }^{2}$ According to the legal theory as a method of legal practice, the legal theory was emphasized to the rule-making (legislation) and interpretation. ${ }^{3}$

An important instrument of political parties in a democracy lies in a particular role given to parties as institutions that carry the people's aspirations. ${ }^{4}$ The political parties distribute and relocate a socio-political power to the state's political superstructure level through the general elections. ${ }^{5}$ The existence of political parties in Indonesia coincided with developing the right to express the people's thoughts or ideas and the right to organize. ${ }^{6}$ In his book "Political Order in Changing Societies," Huntington states that the development of democracy has increased people's political participation in the life of the nation and state. ${ }^{7}$ The most important political parties' instrument lies in their special role in distributing the people's aspirations and relocating the socio-political power to the election. Consequently, the political parties must be works according to the 1945 Constitution of the Republic of Indonesia, which contains the basic principle of democracy and the political system.

1 Yohanes Suhardin, "Peranan Hukum Dalam Mewujudkan Kesejahteraan Masyarakat" (2007) 25:3 Jurnal Hukum Pro Justitia, at. 270.

2 Barda Nawawi Arief, Masalah Penegakan Hukum dan Kebijakan Hukum Pidana Dalam Penanggulangan Kejahatan (Jakarta: Prenada Media, 2018) at 25.

3 Arief Sidharta, Meuwissen Tentang Pengembangan Hukum, Ilmu Hukum, Teori Hukum, dan Filsafat Hukum (Bandung: Reflika Aditama, 2007) at 29.

4 Abdul Manan, Aspek-Aspek Pengubah Hukum (Jakarta: Prenada Media, 2018) at 109.

5 Didik Sukriono, "Desain Pengelolaan Keuangan Partai Politik Berbasis Demokrasi Menuju Kemandirian Partai Politik" (2018) 3:1 Jurnal Ilmu Pendidikan Pancasila dan Kewarganegaraan, at 38.

6 Anwar Rachman, Hukum Perselisiban Partai Politik (Jakarta: Gramedia Pustaka Utama, 2016) at. 83-84.

7 Samuel P. Huntington, Tertib Politik di Tengah Pergeseran Kepentingan Masa, Terjemahan dari Political Order in Changing Societies (Jakarta: Raja Grafindo Persada, 2003) at 472. 
In operating the management of political parties, party administrators have trusted to determine the party's policies' direction. Besides, in the running of a party, it cannot be denied that sometimes there are disputes among the party's administrator members. In the Indonesian case, there was a conflict of internal management within a political party. A special case of the internal conflict of a political party occurred within the Golkar (Golongan Karya) Party in 2014, between Agung Laksono and Aburizal Bakrie Political Party Court to resolve their conflict. ${ }^{8}$ Juridically, political party management disputes have been regulated in Law Number 2 of 2011 on the Amendment to Law Number 2 of 2008 on Political Parties, which specifically regulated in Articles 32 and 37. According to this regulation, one of the rules is a settlement of political party disputes by providing empowerment and independence of the parties through the Political Party Court that should have to be established by the political parties. Unfortunately, the existence of the Political Party Court has not been integratively regulated. It can be seen from the ambiguous and complicated norms in Law Number 2 of 2011, only regulating the party's disputes in Article 2. The ambiguity was also proven by the absence of the procedural arrangements for political party disputes in the Political Party Court. 9

In practice, the procedural law that has been used in examining cases of disputes over political parties is their methods in each political party. A case examined by the court should combine three things simultaneously: legal certainty, utility, and justice. Thus, strengthening and institutionalizing the Political Party Court will be based on these three points. It considers the Political Party Court as an institution that will ensure and guard the political parties' sovereignty. ${ }^{10}$ The urgency of structuring the Political Party Court is aimed to provide legal protection, especially for every member of the political party as a citizen's right and their right as a party member. ${ }^{11}$

8 Ade Mulyawan, “Konflik Internal Partai Golkar Pasca Pemilihan Umum 2014” (2014) UIN Syarif Hidayatullah, at 9.

9 Firdaus Firdaus \& Nalom Kurniawan, "Kekuatan Putusan Mahkamah Partai Ditinjau dari Sistem Kekuasaan Kehakiman Menurut UUD 1945” (2018) 14:3 Jurnal Konstitusi at 665.

10 Fitria Agustina, "Kedudukan Mahkamah Partai Politik Dalam Penyelesaian Sengketa Internal Berdasarkan Undang-Undang Nomor 2 Tahun 2011” (2015) Universitas Jember, at 47.

11 Charlyna S Purba, "Eksistensi Mahkamah Partai Persatuan Pembangunan (Studi Putusan Mahkamah Partai Dewan Pimpinan Pusat Partai Persatuan Pembangunan No. 49/PIP/MP-DPP.PPP/2014)" (2020) 1:1 Jurnal Hukum Media Bhakti, online: <http://journal.fhupb.ac.id/index.php/jhmb/article/view/4> at 11. 


\section{THE PROCEDURES OF THE POLITICAL PARTY COURT IN THE PARTY DISPUTE SETTLEMENT}

\section{A. The Progress of the Regulation of the Political Party Court}

From a legal perspective, the progress in regulating the Political Party Court can be traced by comparing the Political Party's Law in the past and the successive year, starting with Law Number 2 of 1999 on Political Parties. This regulation does not contain how to resolve internal political party disputes. Law number 2 of 1999 does not raise the issues of internal political party dispute settlement. ${ }^{12}$ The basic principles of the political party at that time still revolve around the matter of the requirements of party's establishment, party's principles, party's objectives, party's rights, party's finances, and party's suspension or dismissal. Anyone who feels aggrieved by the political party's decision, this dispute will be submitted and examined by the District Court. The legal basis used to accuse the cases of party dispute to the District Court is Article 1365 of the Civil Code of illegal acts committed by party officials against the members of political parties. ${ }^{13}$

Law number 31 of 2002 on Political Parties came to replace the previous regulation (Law number 2 of 1999). This law has started to introduce a dispute settlement of political parties. However, a brief and vague norm still regulates it. ${ }^{14}$ Article 16, Chapter VIII of the Law number 31 of 2002 entitled The Court of Political Party Cases- arranges that the cases of political parties relating to this law's provisions are filed and solved through the District Court. The District Court must settle the political party cases for a maximum of sixty days and by the Supreme Court for a maximum of thirty days. ${ }^{15}$ However, the problem that arises is whether the political party case arranged by Law number 31 of 2002 has included the scope of internal political party disputes. Suppose it is traced according to the provisions of Article 16 section (1) regarding the cases of the political party that can be settled by the District Court. In that case, there is a phrase 'relating to this law.' This phrase means that the cases which can be processed to the District Court include the offense of Article 19 section (2) relating to the prohibition for political parties from carrying out certain activities; the offense of Articles 18 and 19 section (3) related to the prohibition of donations to the political

\footnotetext{
12 Agus Satory et al, Meneroka Relasi Hukum, Negara, dan Budaya (Jakarta: Yayasan Pustaka Obor Indonesia, 2017) at 61.

13 Anwar Rachman, supra note 3 at 188.

14 Satory et al, supra note 12 at 61.

15 Ibid at 62.
} 
parties; as well as the offense of Article 19 section (5) related to the prohibition for political parties from adhering, extending and spreading the Communism, Marxism, Leninism.

Referring to the normative provisions of Law number 31 of 2002, these circumstances which can be settled through the District Court as regulated in this Law are not included in an internal political party's disputes. The internal political party disputes are not regulated in this law. Nevertheless, there is no prohibition against using the District Court or alternative dispute settlement as long as it has been regulated in each party's statute.

Furthermore, there was also Law Number 2 of 2008 on Political Parties, which replaced all the previous law. The settlement of political party disputes is regulated in this Law for the first time, which is arranged by Article 32. This article explains that political party disputes can be resolved by confabulation and consensus methods. If the consensus cannot be reached, then the settlement of political party disputes can be pursued through litigation or non-litigation. ${ }^{16}$ The non-litigation dispute settlement that is solved from the outside of the court can be through by reconciliation, mediation, or arbitration by the political parties where the mechanisms are regulated in their statute. ${ }^{17}$ This law does not regulate the existence of a Political Party Court, and there is no obligation for political parties to establish a Political Party Court. ${ }^{18}$

In the development of the regulations regarding the political parties, Law number 2 of 2011 as the newest regulation on Political Parties was the last amended law and is currently being used. The provisions regarding the regulation of party's internal dispute in this Law have significantly evolve compared to Law number 2 of 2008. ${ }^{19}$ This newest political party's law accommodates a Political Party Court or other designation in resolving the internal party disputes. Law number 2 of 2011 has mandates every political

16 Rizky Perdana Maya, "Kewenangan Mahkamah Partai Sebagai Lembaga Penyelesaian Perselisihan Internal Partai Politik" (2016) Universitas Andalas, at 9.

17 Agustina, supra note 10 at 43-45.

18 A A Oka Mahendra, "Paradigma Baru UU No. 2 Tahun 2008 Tentang Partai Politik" (2018) 5:1 Jurnal Legislasi Indonesia 81-89.

19 Satory et al, supra note 12 at 66. 
party to establish a Political Party Court. However, the Political Party Court has not clearly defined by this law. ${ }^{20}$

As the party's internal disputes, which regulated in Article 32 section (2), states, to strengthen the implementation of democracy and an effective party's system according to the state constitution, it is necessary to strengthen the institutions and to increase the function and role of the political parties. ${ }^{21}$ The adjustment of political party dispute settlement is listed in Articles 32 and 33 to regulate the patterns of acceleration of the dispute settlement and obligate the political parties to establish a Political Party Court. This obligation will make the Political Party Court replace the District Court's authority, which has the authority to adjudicate the internal disputes of the political parties. ${ }^{22}$

\section{B. Party's Court In The Party's Statute}

The Political Party Court's function in resolving internal conflicts of political parties is regulated in Law Number 2 of 2011 on Amendments to Law Number 2 of 2008 on Political Parties, which is arranged by article 32 and article 33. The establishment of this party's court is expected to encourage political parties' independence by settling their internal disputes without interference from the government or judicial institutions. This provision is appropriate with Article 12 letter (b) of the Political Party Law, which states that the political parties have the right to regulate and manage their organizational households independently. Political parties' independence and obligation are resolving their internal disputes by establishing their professional and independent courts. This mechanism will construct the good, effective, strong, independent, professional, and functional parties as a result. ${ }^{23}$

20 Kristo Roland Pattiapon, "Eksistensi Mahkamah Partai Politik dalam Menyelesaikan Perselisihan Internal Partai Politik" (2020) 5:1 Jurnal Ilmu Pendidikan Pancasila dan Kewarganegaraan 85-94 at 91.

${ }^{21}$ IK Ghoniyyah, "Peran dan Fungsi Mahkamah Partai dalam Menyelesaikan Konflik Internal Partai Menurut Undang-Undang No. 2 Tahun 2011 tentang Partai Politik" (2016) Universitas Islam Negeri Sunan Ampel Surabaya at 50.

22 Ali Mahbub, "Problematika Status Putusan Mahkamah Partai Politik Dalam Penyelesaian Sengketa Partai Politik: Studi Atas Politik Hukum Pasal 32 dan Pasal 33 Undang-Undang Nomor 2 Tahun 2011 tentang Partai Politik" (2018) Universitas Islam Indonesia, at 66.

23 Agustina, supra note 10 at 54 . 


\section{The Procedures of the Political Party Court}

In the political Party Court procedure in internal dispute settlement, the existence of this party courts that already has Court proceedings within the party's internal dispute is only two parties, namely the Golkar Party and the Partai Persatuan Pembangunan (the development union party). Both if these parties already have special rules in the Party Organization Regulations regarding the Party Court procedures. ${ }^{24}$ The procedure for the Political Party Court in the Golkar Party includes the Petitioners. In this court, the petitioner is the people who accuse or an individual who perceive to be aggrieved by the party's policy. This provision can be seen in Article 2 section (1) of the Golkar's statute. The other side of the party's dispute is the defendant who officially posts as party leaders on the local or national stage.

The Golkar's Court procedures are. First, the petitioner submits the petition for internal disputes to the Golkar Party, referred to in Article 2 section (1). Regarding the petition, based on Article 6 section (1) and section (2) of the Golkar Party Organizational Regulation states that relating to the management disputes, abuse of management authority, financial accountability, and the exception of the party's decisions must be submitted within a maximum of 14 (fourteen) weekday since the party's decision by the DPP Golkar Party/ DPD has issued, or since the petitioner receives this decree accompanied by a receipt as proof. The petition, which is related to violations of the party members' rights, and the dismissal of party members/party functionary without any apparent reason, can be submitted within a maximum period of 90 (ninety) days since the dispute has occurred. The petitioner's application must conform to several matters as stipulated in Article 7 section (1) and (2). Article 7 sections (1) and (2) explain that the petition must at least contain the identity (name, address, telephone number (office, house, cellphone), facsimile number, and/or e-mail), the authority of the Party Court, the legal standing of the petitioner, and the deadline for Submitting the Application. Besides, the petitioner is obliged to provide a clear description of the petition regarding the chronology of the occurrence and the reasons and the requisition. The petition requested must be equipped with the piece of evidence that promotes the petition. Article 7 section (3) states that the evidence referred to in section (2) are letters or documents. In this condition, the Petitioner must submit 10 (ten) copies of evidence that

${ }^{24}$ Tri Cahya Indra Permana, "Model Penyelesaian Perselisihan Partai Politik Secara Internal Maupun Eksternal” (2016) 5:1 Jurnal Hukum dan Peradilan, at 39. 
one copy must be stamped with the seal. The other (nine copies) are the multiplication of the evidence.

Second, the registration and trial schedule. The provisions of the Political Party Court in registration and the trial are explained in Article 10 of the Golkar Party Organization Regulation. This article states that applications received will be recorded by the Registrar in the Case Registration Book (BRP). Further, the Secretariat of the Party Court will send a copy of the petition that has been recorded in the BRP to the defendant, accompanied by request for a written response or exception from the defendant and the first trial scheduled for the petitioner and the defendant within three weekday. The written answer made by the defendant shall at least contain the name and address, office telephone number, facsimile number, electronic mail (e-mail), a clear argument of the rebuttal, the chronology of the imposition of sanctions for the petitioner, publishing the decisions, the infringement of the decision, disputes and/or presumption of abuse of the authority along with the reasons.

When the defendant's answer or exception has been received by the Registrar's Office no later than a weekday before the trial day, the next process is the Plenary Trial of the Party Court, which is conducted to hear the Petitioner's Explanation, Defendant's Response. The parties' evidence, followed by the third party's statements (optional), conclusion, and the final process is the Decision. For evidentiary, the Party Court can initiate an adjudication process through a virtual trial (video conference) and/or other communication media such as facsimile and electronic mail (e-mail).

There are still weaknesses in the procedures of the Golkar Party Political Court. In the case of Judges' selection, there are still no requirements and an ideal term for presiding over the trial, which is very important to avoid intervention from others. There is no legal form and specific rules regarding the procedures for the Political Party Court. Therefore, it requires creating an ideal concept of a Political Party Court - for all parties- or the reformation of the party court's procedures in internal dispute settlement for the fluency and accountability of this court. 


\section{REFORM OF COURT PROCEDURES IN THE PARTY DISPUTE SETTLEMENT SYSTEM}

\section{A. The Legal Concept}

The standing of the Political Party Courts is still relatively weak, either from the perspective of regulation, instruments, and litigation processes ${ }^{25}$. The political Party Court's procedural arrangements in Indonesia need to be organized and improved through the regulation to create a democratic political system and raise an effective presidential system. ${ }^{26}$ One of the main elements that need to be more comprehensively regulated is the restructuration of the party's court in the Political Party Law by giving more independence to the political parties related to their internal disputes and assigning a procedural rule for the Political Party Court. ${ }^{27}$ The Political Party Court must have functioned as an institution that performs "pro-Justicia" actions and law enforcement in general terms and the necessity for resolving internal party disputes. The establishment of the Political Party Court aims to accelerate the settlement of internal party's disputes.

\section{B. The Judges}

In the judges' recruitment process at the Political Party Court, the party's leader elects and appoints the judges from their members. In order to be appointed as a Judge and a member of the Panel of Judges, people should fulfill the following requirements: ${ }^{28}$

a. Indonesian Nationality;

b. Believe in God Almighty;

c. Faithfull to the Pancasila and the 1945 Constitution;

d. Have an education of at least a Bachelor degree (S1), specifically Bachelor of Laws;

e. Be at least 40 (forty) years old;

f. Physically and mentally healthy;

g. Be prestigious, truthful, fair, and undespicable behavior; and

h. Experienced as a party member and/or committee for a minimum of 10 years.

25 Firdaus \& Kurniawan, supra note 9 at 660.

26 Anwar Rachman, supra note 3 at 40.

27 Ibid at 41.

28 Ibid at 356. 
The Party Court judge is obliged to take an oath or pledge before taking the position. For these eight requirements, most of them have included the administrative requirements, which mean they can sufficiently be fulfilled by showing the evidence of administrative documents. The technical requirements that were measured are professionality, such as skills in conducting legal analysis and arguments. It is also necessary to have qualitative requirements such as belief in God Almighty, integrity, dignity, honesty, fairness, and undespicable behavior. Both of these personal and professional requirements need to be more detailed in regulation to ensure the judges' integrity to occupy this honorable position..$^{29}$

\section{The Authorities of The Court}

The types of the disputes which can be requested for examined to the Political Party Court according to the law are the disputes relating to the party's management; violation of the rights of party members; dismissal or suspension of the management without clear reasons; abuse of power; dismissal of the DPR members from political parties; and an exception of the decision issued by the higher stewardship. ${ }^{30}$

Regarding the petition, the Petitioners originated from each party -which is proven by a Party Member Card issued by the legal management and/or Party's Councils in any levels- who feel disadvantaged by some previous disputes. The defendant is the Party Governing Council, which issues a decision relating to the defendant who is petitioned to be recalled or filed into the dispute. The members or Party Governing Council who feel the party's decision has aggrieved their interests may submit a written lawsuit to the Party Court containing the demand for this decision to be canceled and unlawful declared, with or without demands for rehabilitation. The reasons that can be used to this petition are the party's decision contradicts the prevailing regulations and Party's Statutes; contradicts with the principles of legal certainty, administrative order, transparency, proportionality, professionality, accountability; and other management-related matters, whether in the case of dismissal or suspension without clarity, abuse of authority, financial accountability, and exception to the decisions issued by superiors. ${ }^{31}$

\footnotetext{
${ }^{29}$ Ibid.

30 Firdaus \& Kurniawan, supra note 9 at 657.

${ }^{31}$ Anwar Usman, supra note 6 at 356.
} 
In submitting the petition, the Petitioner must be a person or entity with a direct interest in the party dispute. The procedures for submitting the petition are:

1. The petition must be submitted in written Indonesian language by petitioner to the Party Court;

2. The petition must be signed by the petitioner and made in 6 (six) copies;

3. The application contains at least:

a. Complete identity of the petitioner;

b. A clear and detailed description of the types of violations by the management and the decision letter petitioned for annulment, which is deemed contrary to the Party Law, statutes/articles of association, and Party Regulations;

c. Evidence supporting the petition; and

d. Request or demand to withdraw the party's decision letter.

4. This petition for annulment of a party decision may be submitted not later than 60 (six) days counted from the date of the decision and/or the notification of the decision concerned;

5. The petition submitted after passing the date as intended in section (4) cannot be registered in the party's court.

Subsequently, the Political Party Court will determine the first trial scheduled in a maximum of seven weekdays after the petition was recorded in the Party Court Case Registration Book (BRP). The parties will announce the first trial to the parties and the public by an official website. ${ }^{32}$

\section{The Trials}

The examination of the petition shall be carried out in an opened trial, attended by at least 3 (three) members of the judges. The first trial is the preliminary examination to verify the file completeness, identity of the parties, and the petition's clarity. At the first trial, the Panel of Judges advised the Petitioner to complete or revise the petition if deemed necessary in a maximum of seven days. Before the trial started, the chief and/or the judges' members must attempt to reconcile the disputing parties. ${ }^{33}$

If the reconciliation can be achieved, it can be stated in the judges' decision, and the parties are required to obey this decision. In the trial, the parties are

$32 \quad$ Ibid at 367.

33 Ibid at 255. 
given the same opportunity to convey their arguments and/or abutment, either verbally or in writing, equipped with the evidence which consists of statements from the parties; letters or documents; witness statement; expert testimony; clues; other evidence such as electronic information; and letters or documents which has submitted as evidence in the trial. ${ }^{34}$

Furthermore, the Assembly Consultative Meeting (RPM) was held to decide after the judges' trial examination was deemed sufficient. This RPM must be carried out in a private meeting by the Plenary of the judges, which are attended by a minimum of 3 (three) judges. The deliberation process holds decision-making in the RPM to achieve a consensus. If the consensus has not been achieved, a decision will be made on the majority votes. If a majority vote cannot reach a decision, the final vote will be determined by the chief of the Judges of RPM.

\section{E. The Decision}

The execution or implementation of the decision has legally binding authority. It can be enforced for the losing party (the defendant) if the decision was disobeyed. In principle, only a legally binding decision (inkracht van gewijsde) can be enforced. The decisions which can be executed are decisions that have obtained permanent legal force (inkracht van gewijsde), which contains an Intent of a fixed and definite legal relationship between the parties in this case. When this legal relationship between the parties has been fixed, it must be obeyed and fulfilled by the convicted party (the defendant).

The decision of the Political Party Court applies to the internal party concerned. The parties must obey the party's decisions relating to the 4 (four) cases related to political party management. The KPU considers the Party Court's decision to determine the right to nominate candidates for president, governor, or regent and is also used by the police to safekeeping the political parties' building or events. ${ }^{35}$ The Party Court's decision is adopted by the Ministry of Home Affairs, Provincial Governments, and City's Governments to disburse the party's aid funds and used by the Minister of Law and Human Rights to ratify the management of political parties. ${ }^{36}$

34 Ibid.

35 Ibid at 366-367.

${ }^{36}$ M Anwar Rachman, "Penyelesaian Perselisihan Internal Partai Politik" (2017) 31:2 Yuridika 189 at 203. 
Decisions of the Party Court relating to dismissal of political party members are used by the President, KPU, and the chief of the DPR to process the appeal of interim replacement (PAW) for DPR members, Governors, or Regents; and also used by KPU to process recall's applications for DPRD members. ${ }^{37}$

The decision of the Party Court is regulated in Article 33 section (1). This article explains that when the dispute settlement cannot be reached, the District Court can hold the dispute settlement. ${ }^{38}$ However, this is contrary to its absolute authority ${ }^{39}$ because the Political Parties Court decisions tend to be administrative, while the District Courts are not authorized to examine an administrative case. Administrative cases fall under the State Administrative Court's authority, and the District Courts should not have the right to interfere because they did not have the authority. The legal remedy concept is unclear, whether it is a new lawsuit, appeal, or resistance (verset), and whether the Party Court can be withdrawn as a party or not. ${ }^{40}$ The Party Court's decision prevails to internal political parties. It prevails to external political parties and the parties which related the disputes. ${ }^{41}$

\section{E. Trial's Procedures}

The trial stages in the Political Party Court should adopt the stages from the State Administrative Court. The absolute authority of the Party Court, which has the right to decide matters of party management, is an administrative matter because it is related to the decrees of the Central Executive Council (DPP) or the Regional Executive Council (DPD) and the Branch Executive Council which put on trial. If the District Court settled these disputes, it would be contrasted to absolute authority. The District Court was not authorized to adjudicate an administrative case. The party dispute case is an internal decree related to party management issues. This character can be the reasoning that the Party Court- in conducting internal party dispute settlement procedures- can adopt the State Administrative Court's procedures because they have the same absolute authority.

37 Anwar Usman, supra note 6 at 366-367. See also Jayus, Muhammad Bahrul Ulum \& Moch Marsa Taufiqurrohman, "Examining Recall of the House Member: How Does It Impact on Eradicating Corruption in Indonesia?" (2020) 7:1 Lentera Huk 101-116.

38 Pattiapon, supra note 20 at 88.

39 Rachman, supra note 36 at 198.

40 Anwar Usman, supra note 6 at 568.

${ }^{41}$ Ibid at 367. 
Accordingly, the Political Party Court can undertake the trials with the principles of justice and accountability without interference from other parties. $^{42}$

\section{CONCLUSION}

The reform of the Political Party Court proceedings in internal political party disputes - as a legal arrangement for the settlement of political party dispute cases as regulated in Law No. 2 of 2011 on Political Parties- has not applied simple, fast, and low-cost judicial principles. Courts must be under the principles of simple, fast, and low-cost trials. However, this principle has not been adopted in the party dispute settlement. The lack of this principle in the party court can be seen in the party court decision, which should tend to final and binding. The party court decision was still possibly appealed to the district court and the Supreme Court as a final legal effort. ${ }^{43}$ These procedures are still complicated, inefficient, high-priced, and there is no legal certainty and justice for litigation parties. Instead, it can create the dispute settlement's dualism between the District Court and the State Administrative Court. ${ }^{44}$ Relating with the political party court procedures in settlement of internal political party disputes, it is required to comply with the statutes according to Law Number 2 of 2011 on Political Parties. Article 32 section (1) of the Political Party Law states that one of the Political Party Court authorities is to adjudicate the political party disputes as regulated in the statutes. ${ }^{45}$

The Party Organization Regulations recently still limited regulating the Party Court's dispute settlement, regulated in Party statute. However, practically, there are no advanced procedures for their party's court. Reformulation is rearranging the rules that have been established so that they can be suitable with the law. Therefore, the proceedings of the Political Party Court, along with other provisions, must be immediately amended for the internal political party's fluency. The arrangements for solving the political party disputes in the Political Party Law must be immediately repealed and

42 Pattiapon, supra note 20 at 91.

${ }^{43}$ Firdaus \& Kurniawan, supra note 9 at 669.

44 Permana, supra note 24 at 38.

45 Pattiapon, supra note 20 at 90. 
replaced with a new comprehensive law that provides legal certainty for litigation parties.

The propositions given by the author are, first, the urgency of regulating the internal dispute settlement through the political party court under the statute. Second, the amendment of Law number 2 of 2011 on Political Parties related to the additional obligation for each party to have a Political Party Court, its procedures, and the independence of the political parties related to dispute resolution must be strengthened. Then, the legal form as a fundamental part of the law-making process must be immediately improved to unleash the parties' internal management and other provisions, namely the Panel of Judges, the petitioner's legal standing, the stages of the trial, and decision.

\section{REFERENCES}

Agustina, Fitria. "Kedudukan Mahkamah Partai Politik Dalam Penyelesaian Sengketa Internal Berdasarkan Undang-Undang Nomor 2 Tahun 2011” (Universitas Jember, 2015).

Ali, Zainudin. Metode Penelitian Hukum (Jakarta: Sinar Grafika, 2011).

Arief, Barda Nawawi. Masalah Penegakan Hukum dan Kebijakan Hukum Pidana Dalam Penanggulangan Kejahatan (Jakarta: Prenada Media, 2018).

Budiarjo, Miriam. Pengantar Politik (Jakarta: Gramedia, 2000).

Firdaus, Firdaus \& Nalom Kurniawan. "Kekuatan Putusan Mahkamah Partai Ditinjau dari Sistem Kekuasaan Kehakiman Menurut UUD 1945” (2018) 14:3 Jurnal Konstitusi.

Ghonniyyah, IK. " Peran dan Fungsi Mahkamah Partai dalam Menyelesaikan Konflik Internal Partai Menurut Undang-Undang No. 2 Tahun 2011 tentang Partai Politik" (Universitas Islam Negeri Sunan Ampel Surabaya, 2016).

Huntington, Samuel P. Tertib Politik di Tengah Pergeseran Kepentingan Masa, Terjemahan dari Political Order in Changing Societies (Jakarta: Raja Grafindo Persada, 2003).

Ibrahim, Jhony. Teori dan Metode Penelitian Hukum Normatif (Malang: Bayumedia Publishing, 2006). 
Mahbub, Ali. "Problematika Status Putusan Mahkamah Partai Politik Dalam Penyelesaian Sengketa Partai Politik: Studi Atas Politik Hukum Pasal 32 dan Pasal 33 Undang-Undang Nomor 2 Tahun 2011 tentang Partai Politik" (Universitas Islam Indonesia, 2018).

Mahendra, A A Oka. "Paradigma Baru UU No. 2 Tahun 2008 Tentang Partai Politik” (2018) 5:1 Jurnal Legislasi Indonesia.

Manan, Abdul. Aspek-Aspek Pengubah Hukum (Jakarta: Prenada Media, 2018).

Marzuki, Peter Mahmud. Penelitian Hukum (Jakarta: Kencana Prenada Group, 2010).

Maya, Rizky Perdana. "Kewenangan Mahkamah Partai Sebagai Lembaga Penyelesaian Perselisihan Internal Partai Politik" (Universitas Andalas, 2016).

Mulyawan, Ade. "Konflik Internal Partai Golkar Pasca Pemilihan Umum 2014" (UIN Syarif Hidayatullah, 2014).

Pattiapon, Kristo Roland. "Eksistensi Mahkamah Partai Politik dalam Menyelesaikan Perselisihan Internal Partai Politik" (2020) 5:1 Jurnal Ilmu Pendidikan Pancasila dan Kewarganegaraan.

Huntington, Samuel P, Political Order in Changing Societies (Yale University Press, 2006).

Maya, Rizky Perdana, Kerwenangan Mahkamah Partai Sebagai Lembaga Penyelesaian Perselisiban Internal Partai Politik (diploma, Universitas Andalas, 2016).

Anwar Rachma, SH, Hukum Perselisiban Partai Politik (Gramedia Pustaka Utama, 2016).

Abdul Manan, Aspek-aspek Pengubah Hukum (Prenada Media, 2018).

Satory, Agus et al, Meneroka Relasi Hukum, Negara, dan Budaya (Yayasan Pustaka Obor Indonesia).

Barda Nawawi Arief, Masalab Penegakan Hukum dan Kebijakan Hukum Pidana Dalam Penanggulangan Kejahatan (Prenada Media, 2018).

Sidharta;, Arief, Meuwissen Tentang Pengembanan Hukum, Ilmu Hukum, Teori Hukum, Dan Filsafat Hukum (Reflika Aditama, 2007). 
Agustina, Fitria, "Kedudukan Mahkamah Partai Politik Dalam Penyelesaian Sengketa Internal Berdasarkan Undang-Undang Nomor 2 Tahun 2011" (2015), online: <http://repository.unej.ac.id/handle/123456789/67771>.

Firdaus, Firdaus \& Nalom Kurniawan, "Kekuatan Putusan Mahkamah Partai Ditinjau dari Sistem Kekuasaan Kehakiman Menurut UUD 1945” (2018) 14:3 J Konstitusi 644-671.

Jayus, Muhammad Bahrul Ulum \& Moch Marsa Taufiqurrohman, "Examining Recall of the House Member: How Does It Impact on Eradicating Corruption in Indonesia?” (2020) 7:1 Lentera Huk 101-116.

Mahendra, A A Oka, "Paradigma Baru Uu No. 2 Tahun 2008 Tentang Partai Politik” (2018) 5:1 J Legis Indones 81-89.

Mulyawan, Ade, "Konflik Internal Partai Golkar Pasca Pemilihan Umum 2014" (2014), online:

<http://repository.uinjkt.ac.id/dspace/handle/123456789/39118>.

Pattiapon, Kristo Roland, "Eksistensi Mahkamah Partai Politik dalam Menyelesaikan Perselisihan Internal Partai Politik" (2020) 5:1 J Ilm Pendidik Pancasila Dan Kewarganegaraan 85-94.

Permana, Tri Cahya Indra, "Model Penyelesaian Perselisihan Partai Politik Secara Internal Maupun Eksternal” (2016) 5:1 J Huk Dan Peradil 35-52.

Purba, Charlyna S, "Eksistensi Mahkamah Partai Persatuan Pembangunan (Studi Putusan Mahkamah Partai Dewan Pimpinan Pusat Partai Persatuan Pembangunan No. 49/PIP/MP-DPP.PPP/2014)" (2020) 1:1 J Huk Media Bhakti, online: <http://journal.fhupb.ac.id/index.php/jhmb/article/view/4>.

Rachman, M Anwar, "Penyelesaian Perselisihan Internal Partai Politik" (2017) 31:2 Yuridika 189.

Sukriono, Didik, "Desain Pengelolaan Keuangan Partai Politik Berbasis Demokrasi Menuju Kemandirian Partai Politik" (2018) 3:1 J Ilm Pendidik Pancasila Dan Kewarganegaraan 37-46.

Rachman, H. M. Anwar. Hukum Perselisihan Partai Politik (Jakarta: Gramedia Pustaka Utama, 2016). 
Rachman, M Anwar. "Penyelesaian Perselisihan Internal Partai Politik" (2017) 31:2 Yuridika.

Satory, Agus et al. Meneroka Relasi Hukum, Negara, dan Budaya (Jakarta: Yayasan Pustaka Obor Indonesia, 2017).

Sidharta, Arief. Meuwissen Tentang Pengembanan Hukum, Ilmu Hukum, Teori Hukum, dan Filsafat Hukum (Bandung: Reflika Aditama, 2007).

Suhardin, Yohanes. "Peranan Hukum Dalam Mewujudkan Kesejahteraan Masyarakat" (2007) 25:3 Jurnal Hukum Pro Justitia.

Sukriono, Didik. "Desain Pengelolaan Keuangan Partai Politik Berbasis Demokrasi Menuju Kemandirian Partai Politik” (2018) 3:1 Jurnal Ilmu Pendidikan Pancasila dan Kewarganegaraan. 